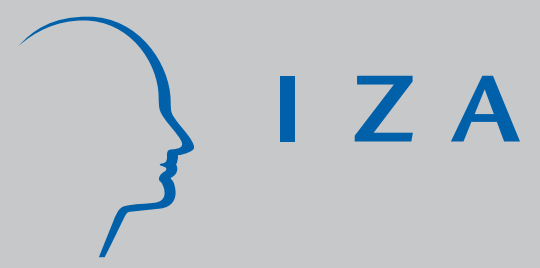

IZA DP No. 215

The Effect of Parents' Employment on Children's Educational Attainment

J ohn Ermisch

Marco Francesconi

November 2000 


\title{
The Effect of Parents' Employment on Children's Educational Attainment
}

\author{
John Ermisch \\ Institute for Social and Economic Research, \\ University of Essex and IZA, Bonn \\ Marco Francesconi \\ Institute for Social and Economic Research \\ University of Essex and IZA, Bonn \\ Discussion Paper No. 215 \\ November 2000 \\ IZA \\ P.O. Box 7240 \\ D-53072 Bonn \\ Germany \\ Tel.: +49-228-3894-0 \\ Fax: +49-228-3894-210 \\ Email: iza@iza.org
}

\begin{abstract}
This Discussion Paper is issued within the framework of IZA's research area The Future of Work. Any opinions expressed here are those of the author(s) and not those of the institute. Research disseminated by IZA may include views on policy, but the institute itself takes no institutional policy positions.

The Institute for the Study of Labor (IZA) in Bonn is a local and virtual international research center and a place of communication between science, politics and business. IZA is an independent, nonprofit limited liability company (Gesellschaft mit beschränkter Haftung) supported by the Deutsche Post AG. The center is associated with the University of Bonn and offers a stimulating research environment through its research networks, research support, and visitors and doctoral programs. IZA engages in (i) original and internationally competitive research in all fields of labor economics, (ii) development of policy concepts, and (iii) dissemination of research results and concepts to the interested public. The current research program deals with (1) mobility and flexibility of labor markets, (2) internationalization of labor markets and European integration, (3) the welfare state and labor markets, (4) labor markets in transition, (5) the future of work, (6) project evaluation and (7) general labor economics.
\end{abstract}

IZA Discussion Papers often represent preliminary work and are circulated to encourage discussion. Citation of such a paper should account for its provisional character. 
IZA Discussion Paper No. 215

November 2000

\section{ABSTRACT \\ The Effect of Parents' Employment on Children's Educational Attainment}

This paper presents the conditions under which a causal interpretation can be given to the association between childhood parental employment and subsequent education of children. In a model in which parental preferences are separable in own consumption and children's wellbeing, estimation is complicated by endowment heterogeneity and by the fact that parents may compensate or reinforce children's endowments relevant to educational attainment. A sibling difference estimation strategy is generally not sufficient to provide a consistent estimate of the parameter of interest. Identification rests on two stronger assumptions about the timing of parents' knowledge of their children's endowments and about the technology used to produce children's human capital. We find a negative and significant effect on the child's educational attainment of the extent of mother's full-time employment when the child was aged 0-5. The effects of mother's part-time employment and father's employment are smaller and less well determined but again negative. In the context of our conditional demand function framework, these results suggest that a higher full family income increases the educational attainment of children, and given full family income, a higher mother's or father's wage reduces their children's educational attainment.

JEL Classification: I21, J13, J22, J24

Keywords: Intergenerational links, sibling estimators, endowment heterogeneity, conditional demand functions

Marco Francesconi

ISER

University of Essex

Colchester CO4 3SQ

UK

Tel.: $+44(0) 1206873534$

Fax: +44 (0) 1206873151

Email:mfranc@essex.ac.uk

\footnotetext{
* We are grateful for financial support from the Joseph Rowntree Foundation under the "Work and Family Life" Programme. This research is part of the program of the ESRC Centre on Micro-social Change at ISER. The financial support of the ESRC is also gratefully acknowledged. Comments and suggestions by Shirley Dex, Greg Duncan, Heather Joshi, Kath Kiernan, Shelly Lundberg, Steve Machin, Elaina Rose, Paul Schultz, Jane Waldfogel, Ken Wolpin and seminar participants at the Universities of Essex and Swansea, at the CERF 2000 Conference (University of British Columbia) and ESPE 2000 Conference (Bonn) greatly improved the paper.
} 


\section{Non-technical summary}

In the last two decades there has been an extensive body of empirical work concerned with the links between parental investment in children and children's outcomes, particularly educational attainment. Most of these studies are implicitly embedded in the household production model introduced by Becker $(1965)(1976 ; 1979 ; 1986)$, and Behrman et al. (1982), but only a few of them attempt to disentangle the household's tastes from its technology in "producing" young people's human capital.

This paper presents a theoretical framework that provides the conditions under which we can give a causal interpretation to the association between childhood parental employment and subsequent education of children as young adults. In an environment in which parental preferences are separable in their own consumption and children's well-being, estimation is complicated by endowment heterogeneity and by the fact that parents may compensate or reinforce children's endowments relevant to educational attainment. While a sibling difference estimation strategy may be useful to eliminate endowment heterogeneity that is common across siblings, it is generally not sufficient to provide a consistent estimate of the parameter of interest. That rests on two stronger assumptions. First, that the idiosyncratic endowments of children are not revealed to parents at birth (it takes time before parents fully know their children's endowments). Second, the parents' time and good elasticities in the children's human capital production function do not vary across ages of the child nor across siblings.

The empirical analysis uses data from various samples of young people drawn from the British Household Panel Survey. There is a negative and significant effect on the child's educational attainment as a young adult of the mother's full-time employment when the child was aged 0-5. The effect of mother's part-time employment is also negative but smaller and less well determined. Similarly, the effect of father's employment is small, not always precisely estimated but again negative. The negative effects of mother's part-time work and, particularly, of mother's full-time work, persist when we include parents' employment patterns over the entire childhood period. In the context of our conditional demand function framework, these results suggest that a higher full family income increases the educational attainment of children, and given full family income, a higher mother's or father's wage reduces their children's educational attainment. 


\section{Introduction}

In the last two decades there has been an extensive body of empirical work concerned with the links between parental investment in children and children's outcomes, particularly educational attainment. ${ }^{1}$ Most of this work is implicitly embedded in the household production model introduced by Becker (1965) and developed by Michael (1973), Leibowitz (1974), Becker (1981), Becker and Tomes (1976; 1979; 1986), and Behrman et al. (1982). Although this model emphasizes the distinction between production technology and preferences, there are only a few studies that attempt to disentangle the household's tastes from its technology in "producing" young people's human capital. $^{2}$

In the literature on educational outcomes, Hanushek (1992) formulates a valueadded model to estimate achievement growth using data on schools, families, and students observed over a four-year period. ${ }^{3}$ Most of the other studies in this literature have estimated education equations that contain one or more education inputs as well as prices and income variables on the right hand side. Since these so called "hybrid equations" (Rosenzweig and Schultz 1983) do not generally embody any restriction derived from economic theory, they cannot provide relevant information on the household's preferences or education technology and their specifications are likely to be arbitrary. Moreover, many of these studies have ignored the possible endogeneity

\footnotetext{
${ }^{1}$ For a detailed overview of existing studies, see Haveman and Wolfe (1995) and Mulligan (1997).

${ }^{2}$ Examples of such studies in the child health literature are Rosenzweig and Schultz (1983), and Grossman and Joyce (1990), which employ instrumental variables techniques, and Rosenzweig (1986), Rosenzweig and Wolpin (1988; 1995), Strauss (1990), and Currie and Cole (1993), which employ data on siblings, half-siblings and cousins to examine how maternal choices and characteristics affect child health outcomes.

${ }^{3}$ Blau et al. (1996) also apply a value-added model to analyse the relationship between infants' health and the labour supply of their mothers.
} 
of education inputs by assuming that young people do not differ in terms of their "endowments" relevant to educational attainment. Therefore, it is not surprising that both the wide variety of specifications and the near total neglect of potential endogeneity problems make "generalizations regarding the absolute and relative effects of potential determinants on attainment virtually impossible" (Haveman and Wolfe 1995, p. 1873).

Several studies have attempted to determine whether parents' (particularly mothers') employment affects children's educational attainment. In reviewing some of the most influential American studies that have examined the effects of early maternal employment on children's early cognitive development, Harvey (1999) underlines that "the results of these studies have been surprisingly mixed considering they used the same data set" (p. 445), that is, the National Longitudinal Survey of Youth. But all of them, including Harvey's own study, estimate hybrid equations and thus confound the technological properties of the education production function and the characteristics of the household's preferences. A similar point can be raised for most of the currently available analyses that use British data, which are concerned either with early learning or with later educational achievements (see Kiernan 1997; Gregg and Machin 1999; Joshi and Verropoulou 2000).

In this paper, we estimate the relationship between parental employment patterns during childhood and children's educational attainment during young adulthood using a "sibling difference" estimator. Although the use of kinship data has become increasingly common in the economic analysis of intergenerational links (Rosenzweig and Wolpin 1995), there is no study attempting to estimate the effect of parental behaviour during childhood on children's later education using a sibling estimator within a framework embedded in economic theory. Other studies have 
employed kinship data to estimate the relationship between maternal employment and children's education (e.g., Duncan et al. 1997; Duncan et al. 1998). But these studies do not estimate the relationship of interest within an economic-theory approach. Rather, by including both measures of mothers' labour supply and parental income, they estimate hybrid equations, which fail to have a meaningful economic interpretation. Yet, a meaningful interpretation is important for evaluation of policies concerned with family leave and work-family balance, and of policies intended to reduce dependency on state benefits and improve family finances by encouraging mothers to take up paid work. ${ }^{4}$

In Section 2 we develop a conceptual framework that allows us to assess the effect of parental behaviour on children's education in the presence of heterogeneity in "endowments". This framework leads to the formulation of conditional demand functions that define the conditions under which we can give a causal interpretation to the association between a parent's employment and future outcomes of her children arising from human capital investment in them. The data are described in Section 3, while Section 4 illustrates the econometric model employed to account for such heterogeneity. Section 5 discusses estimates of the effect of parental employment during childhood and their children's educational attainment as young adults and presents supplementary empirical information relevant to the assumptions needed for identification. Section 6 concludes.

\footnotetext{
${ }^{4}$ For recent policy initiatives in Britain, see Department for Education and Employment (2000).
} 


\section{Framework}

\subsection{A Static Model of Parents' Human Capital Investment in their Children}

It is clear that, in general, the time a mother spends in employment is chosen jointly with human capital investment in her children and parents' own consumption. It would, therefore, be hard to interpret the coefficient of mother's employment time in an equation for her child's eventual educational attainment. Furthermore, there would be no valid instruments for mother's employment, because all exogenous variables, such as her wage and other family income, are also determinants of the child's educational attainment.

There is, however, intuitive appeal in assuming that parents have preferences characterized by a utility function which has earning capacities of children separable from parents' consumption; that is, in the case of a two-child family, parental utility is given by $\mathrm{U}=\mathrm{U}\left(\mathrm{x}, \mathrm{W}\left(\mathrm{e}_{\mathrm{a}}, \mathrm{e}_{\mathrm{b}}\right)\right)$, where $\mathrm{x}$ is parental consumption; $\mathrm{e}_{\mathrm{i}}(\mathrm{i}=\mathrm{a}, \mathrm{b})$ is the future earning capacity of each child $\mathrm{i}$, and $\mathrm{W}($.$) is the sub-utility function representing$ parental welfare from children's earnings. The constraints include two human capital production functions, $e_{a}=f\left(t_{a}, z_{a}, \varepsilon_{a}\right)$ and $e_{b}=f\left(t_{b}, z_{b}, \varepsilon_{b}\right)$, where $t_{i}$ is the mother's time input into human capital production for the $\mathrm{i}$-th child, $\mathrm{z}_{\mathrm{i}}$ is the child-specific input of purchased goods and services and $\varepsilon_{\mathrm{i}}$ is the "earnings endowment" of the i-th child. ${ }^{5}$ The resource constraint is $\mathrm{y}+\mathrm{wT}=\mathrm{x}+\mathrm{w}\left(\mathrm{t}_{\mathrm{a}}+\mathrm{t}_{\mathrm{b}}\right)+\mathrm{p}\left(\mathrm{z}_{\mathrm{a}}+\mathrm{z}_{\mathrm{b}}\right)=\mathrm{x}+\mathrm{R}$, where total mother's time available is $\mathrm{T}, \mathrm{w}$ is the wage of the mother, $\mathrm{p}$ is the price of "child investment goods", $\mathrm{y}$ is father's earnings and other non-earned income, and $\mathrm{R}=\mathrm{w}\left(\mathrm{t}_{\mathrm{a}}+\mathrm{t}_{\mathrm{b}}\right)+\mathrm{p}\left(\mathrm{z}_{\mathrm{a}}+\mathrm{Z}_{\mathrm{b}}\right)$ denotes the resources devoted to human capital investment in children.

\footnotetext{
${ }^{5}$ Relaxation of the assumption that only mothers provide time inputs to human capital investment in children does not alter the main message from the model.
} 
Separable utility implies that $\mathrm{e}_{\mathrm{a}}$ and $\mathrm{e}_{\mathrm{b}}$ can be expressed as functions of $\mathrm{R}, \varepsilon_{\mathrm{a}}$ and $\varepsilon_{b}$, with $\mathrm{w}, \mathrm{p}$ and $\mathrm{y}$ entering these "conditional demand functions" for $\mathrm{e}_{\mathrm{a}}$ and $\mathrm{e}_{\mathrm{b}}$ only through their effect on $\mathrm{R}$ (Pollak 1971). ${ }^{6}$ Unfortunately for econometric purposes, $\mathrm{R}$ is not generally independent of $\varepsilon_{\mathrm{a}}$ and $\varepsilon_{\mathrm{b}}$. It could, however, be instrumented using estimates of $\mathrm{w}$ and $\mathrm{y}^{7}$

There is, however, a special case in which $\mathrm{R}$ and $\mathrm{t}_{\mathrm{a}}+\mathrm{t}_{\mathrm{b}}$ are independent of $\varepsilon_{\mathrm{a}}$ and $\varepsilon_{\mathrm{b}}$. Assume that the production functions take the form $\mathrm{e}_{\mathrm{i}}=\varepsilon_{\mathrm{i}} \mathrm{t}_{\mathrm{i}}^{\alpha 1} \mathrm{z}_{\mathrm{i}}^{\alpha 2}\left(\alpha_{1}+\alpha_{2} \leq 1\right)$, and following Behrman et al. (1982), let $\mathrm{W}\left(\mathrm{e}_{\mathrm{a}}, \mathrm{e}_{\mathrm{b}}\right)=\left[\mathrm{e}_{\mathrm{a}}{ }^{\mathrm{c}}+\mathrm{e}_{\mathrm{b}}{ }^{\mathrm{c}}\right]^{1 / \mathrm{c}}$, with $\mathrm{c} \leq 1$ (i.e. a CES form). The parameter $\mathrm{c}$ indicates the degree of aversion to inequality between children's earnings, with lower c indicating more inequality aversion. It determines whether parents' human capital investments reinforce earnings endowments (c>0) or compensate for differences in children's endowments $(c<0)$. If the parents utility function $\mathrm{U}\left(\mathrm{x}, \mathrm{W}\left(\mathrm{e}_{\mathrm{a},}, \mathrm{e}_{\mathrm{b}}\right)\right)$ is Cobb-Douglas with parameters $\beta$ and 1- $\beta$ respectively, then, letting $\alpha=\alpha_{1}+\alpha_{2}$,

$$
\begin{aligned}
& \ln \left(\mathrm{t}_{\mathrm{a}}+\mathrm{t}_{\mathrm{b}}\right)=\ln \left[(1-\beta) \alpha_{1}\right]-\ln [\beta+(1-\beta) \alpha]+\ln [(\mathrm{wT}+\mathrm{y}) / \mathrm{w}] \\
& \ln \left(\mathrm{e}_{\mathrm{a}}\right)=\alpha \ln \left(\mathrm{t}_{\mathrm{a}}+\mathrm{t}_{\mathrm{b}}\right)+\alpha_{2} \ln (\mathrm{w} / \mathrm{p})+\alpha_{2} \ln \left(\alpha_{2} / \alpha_{1}\right)+\ln \left(\varepsilon_{\mathrm{a}}\right)-\alpha \ln \left[1+\left(\varepsilon_{\mathrm{b}} / \varepsilon_{\mathrm{a}}\right)^{\mathrm{c} /(1-\mathrm{c} \alpha)}\right]
\end{aligned}
$$

with a similar equation for $\ln \left(\mathrm{e}_{\mathrm{b}}\right) .^{8}$

In this case, if $\alpha_{1}$ and $\alpha_{2}$ do not vary across families, we could treat $t_{a}+t_{b}$ as exogenous in the equations for $\mathrm{e}_{\mathrm{i}}$. It would be a 'sufficient statistic' for measuring the effect of $(w T+y) / w$ on $e_{i}$ for constant $w / p$, and this effect would be given by the

\footnotetext{
${ }^{6}$ This is analogous to expressing demand functions within a period as a function of total expenditure in that period in the context of life cycle optimisation and a separable inter-temporal utility function (Blundell and Walker 1986). If the father also provides time inputs to human capital investment, then $R=w_{m}\left(T-h_{m}\right)+w_{f}\left(T-h_{f}\right)+p\left(z_{a}+z_{b}\right)$, where $w_{f}$ and $h_{f}\left(w_{m}\right.$ and $\left.h_{m}\right)$ are the father's (mother's) wage and hours employed.

${ }^{7}$ In the data used in our empirical analysis, however, parental wages and income during young people's childhood are not available.

${ }^{8}$ Derivation of these expressions use the fact that, in this model, optimisation implies that $\mathrm{w}_{\mathrm{a}}\left(\mathrm{t}_{\mathrm{a}}+\mathrm{t}_{\mathrm{b}}\right)=$ $\alpha_{1} \mathrm{R} / \alpha$.
} 
production function parameter $\alpha=\alpha_{1}+\alpha_{2} .{ }^{9}$ Note that we need to control for variation in w/p across families. If the production technology also varied across families, then $t_{a}+t_{b}$ would no longer be exogenous. It would be correlated with the stochastic element of equation (2), because the latter would include $\alpha_{2} \ln \left(\alpha_{2} / \alpha_{1}\right)$.

One way to control for heterogeneity in w/p, $\alpha_{1}$ and $\alpha_{2}$ is to take differences between siblings in families. This static model is not, however, very helpful in structuring such an analysis because $t_{a}+t_{b}$ does not differ between siblings. The static model could be interpreted as one in which non-identical twins are born, or siblings are born close together. The potential for the use of sibling differences in estimating the effect of mother's employment on child outcomes comes from the differences in birthdays for two siblings, but this requires that we consider the dynamics explicitly.

\subsection{A Dynamic Model of Parents' Human Capital Investment in their Children}

In this model, each family is assumed to have two children, each of whom lives for two consecutive periods in the parental home (until the end of childhood) and then moves out. We are therefore concerned with household decisions over three periods. The first child arrives in the first period, and the second in the second period. Parents again choose time and goods inputs to human capital investment in their children and their own consumption. During the second period, both children live with their parents and receive human capital investments from them, while in the first and third period only one child receives such investments. For simplicity, we again assume that only mothers provide time inputs to human capital investment in children. We also assume that there is no borrowing or lending across the periods.

\footnotetext{
${ }^{9}$ Note that, for given "full income" (wT+y), the elasticity of $e_{i}$ with respect to $w$ is $-\alpha_{1}$, and the elasticity of $e_{i}$ with respect to $p$ is $-\alpha_{2}$.
} 
Parents have preferences characterized by a utility function which has earning capacities of children separable from parents' consumption; that is, parental utility is given in each period $\mathrm{j}$ by $\mathrm{U}=\mathrm{U}\left(\mathrm{x}_{\mathrm{j}}, \mathrm{W}\left(\mathrm{e}_{\mathrm{a}}, \mathrm{e}_{\mathrm{b}}\right)\right)$, where $\mathrm{x}_{\mathrm{j}}$ is parental consumption in period $\mathrm{j}(\mathrm{j}=1,2,3)$. The constraints include two human capital production functions, $e_{a}=f\left(t_{1 a}, t_{2 a}, z_{1 a}, z_{2 a}, \varepsilon_{a}\right)$ and $e_{b}=f\left(t_{2 b}, t_{3 b}, z_{2 b}, z_{3 b}, \varepsilon_{b}\right)$, where child a is the first child, born in the first period, and child $\mathrm{b}$ is born in the second period, $\mathrm{t}_{\mathrm{ji}}$ is the mother's time input into human capital production for the $\mathrm{i}$-th child in period $\mathrm{j}, \mathrm{z}_{\mathrm{ji}}$ is the corresponding goods input and $\varepsilon_{\mathrm{i}}$ is the earnings endowment of the $\mathrm{i}$-th child. There is also a parental resource constraint for each period $\mathrm{j}: \mathrm{y}_{\mathrm{j}}+\mathrm{w}_{\mathrm{j}} \mathrm{T}=\mathrm{x}_{\mathrm{j}}+\mathrm{w}_{\mathrm{j}}\left(\mathrm{t}_{\mathrm{ja}}+\mathrm{t}_{\mathrm{jb}}\right)+\mathrm{p}_{\mathrm{j}}\left(\mathrm{z}_{\mathrm{ja}}+\mathrm{z}_{\mathrm{jb}}\right)=\mathrm{x}_{\mathrm{j}}+\mathrm{R}_{\mathrm{j}}$, where $\mathrm{T}$ denotes total mother's time available in period $\mathrm{j}, \mathrm{w}_{\mathrm{j}}$ is the wage of the mother, $\mathrm{p}_{\mathrm{j}}$ is price of child investment goods, $y_{j}$ is father's earnings and other income, $\mathrm{R}_{\mathrm{j}}=\mathrm{w}_{\mathrm{j}}\left(\mathrm{t}_{\mathrm{ja}}+\mathrm{t}_{\mathrm{jb}}\right)+\mathrm{p}_{\mathrm{j}}\left(\mathrm{z}_{\mathrm{ja}}+\mathrm{Z}_{\mathrm{jb}}\right)$ denotes resources devoted to human capital investment in children (in period $\mathrm{j}$ in each instance), and $\mathrm{t}_{1 \mathrm{~b}} \equiv 0 \equiv \mathrm{t}_{3 \mathrm{a}}$ because of the timing of children. The dynamic nature of the problem comes through human capital investment. We shall show that, even in the special case used in the static model, $R_{j}$ is not independent of the children's earnings endowments $\varepsilon_{\mathrm{a}}$ and $\varepsilon_{\mathrm{b}}$. In what follows, we assume CobbDouglas production functions, $\quad \mathrm{e}_{\mathrm{a}}=\varepsilon_{\mathrm{a}} \mathrm{t}_{1 \mathrm{a}}{ }^{\alpha \mathrm{t} 1} \mathrm{z}_{1 \mathrm{a}}{ }^{\alpha \mathrm{z} 1} \mathrm{t}_{2 \mathrm{a}}{ }^{\alpha \mathrm{\alpha} 2} \mathrm{z}_{2 \mathrm{a}}{ }^{\alpha \mathrm{z} 2}$ and $\mathrm{e}_{\mathrm{b}}=$ $\varepsilon_{b} t_{2 b}{ }^{\alpha t 1} z_{2 b}{ }^{\alpha z 1} t_{3 b}{ }^{\alpha t 2} z_{3 b}{ }^{\alpha z 2}\left(\alpha_{t 1}+\alpha_{t 2}+\alpha_{z 1}+\alpha_{z 2} \leq 1\right)$, and $\mathrm{W}\left(e_{a}, e_{b}\right)=\left[e_{a}{ }^{c}+e_{b}{ }^{c}\right]^{1 / c}$, with $c \leq 1$. Notice that the production technology is characterised by identical production elasticities for the two siblings.

This time allocation problem is solved in a backward manner (i.e. starting with the third period). Solving the third period problem (when all human capital investment in the first child has finished), we find that

$$
\partial \mathrm{R}_{3} / \partial \varepsilon_{\mathrm{b}}=\left[\mathrm{c} \beta(1-\beta)\left(\alpha_{\mathrm{t} 2}+\alpha_{\mathrm{z} 2}\right) \mathrm{e}_{\mathrm{b}}{ }^{\mathrm{c}} \mathrm{e}_{\mathrm{a}}{ }^{\mathrm{c}}\right]\left[\partial \ln \left(\mathrm{e}_{\mathrm{b}} / \mathrm{e}_{\mathrm{a}}\right) / \partial \ln \left(\varepsilon_{\mathrm{b}}\right)\right]\left(\mathrm{y}_{3}+\mathrm{w}_{3} \mathrm{~T}\right) / \varepsilon_{\mathrm{b}} \mathrm{D}^{2}
$$


where $D=\left[e_{a}{ }^{c}+e_{b}{ }^{c}\right] \beta+(1-\beta)\left(\alpha_{t 2}+\alpha_{z 2}\right) e_{b}{ }^{c}, \quad \partial R_{3} / \partial \varepsilon_{a}$ is similar, but of the opposite sign. As long as parents respond to their children's individual earnings endowments (i.e. $\mathrm{c} \neq 0), \mathrm{R}_{3}=\mathrm{w}_{3} \mathrm{t}_{3 \mathrm{~b}}+\mathrm{p}_{3} \mathrm{Z}_{3 \mathrm{~b}}$ depends on $\varepsilon_{\mathrm{a}}$ and $\varepsilon_{\mathrm{b}}$, and so neither $\mathrm{R}_{3}$ nor $\mathrm{t}_{3}$ are exogenous in equations for $\mathrm{e}_{\mathrm{a}}$ and $\mathrm{e}_{\mathrm{b}}{ }^{10}$ If parents act to compensate for differences in endowments, a higher endowment for child $b$ (child a) reduces (increases) $R_{3}$ and $t_{3}$, because we expect that $\partial \ln \left(\mathrm{e}_{\mathrm{b}} / \mathrm{e}_{\mathrm{a}}\right) / \partial \ln \left(\varepsilon_{\mathrm{b}}\right)>0 .^{11}$ The opposite is the case if parents reinforce endowment differences in their human capital investment decisions. Similar analysis indicates that neither $R_{1}$ nor $R_{2}$ are exogenous. This conclusion would be the same even if children did not overlap in the time periods of human capital investment.

Sibling difference estimates of the "effect" of mother's employment time on child outcomes often compare the amount of the mother's time devoted to human capital investment when the first child is "young" relative to that when the second child is "young", $\mathrm{t}_{1 \mathrm{a}}-\left(\mathrm{t}_{2 \mathrm{a}}+\mathrm{t}_{2 \mathrm{~b}}\right)$; similarly, the difference in amounts when each child is in the second part of his/her childhood is $\left(t_{2 a}+t_{2 b}\right)-\left(t_{3 b}\right)$. We have shown that these differences are not likely to be exogenous when parents respond to children's endowments.

One possible justification for their exogeneity is that parents do not know these endowments, which is probably more likely when the child is very young, e.g. pre-school age (see Rosenzweig and Wolpin 1995, for an analogous process of information revelation). So let us suppose that $\varepsilon_{\mathrm{a}}$ and $\varepsilon_{\mathrm{b}}$ are not known until the second part of the child's childhood, periods 2 and 3 respectively for child a and b. Then the first period time allocation $\mathrm{t}_{1 \mathrm{a}}$ is independent of $\varepsilon_{\mathrm{a}}$ and $\varepsilon_{\mathrm{b}}$. But

\footnotetext{
${ }^{10}$ Note that $t_{3 b}=\left[\alpha_{12} /\left(\alpha_{12}+\alpha_{22}\right)\right]\left(R_{3} / w_{3}\right)$. In the case of a Cobb-Douglas specification for $W(\cdot), c \rightarrow 0$ and $\mathrm{R}_{3}$ is exogenous.

${ }^{11}$ We expect $\partial \ln \left(\mathrm{e}_{\mathrm{b}} / \mathrm{e}_{\mathrm{a}}\right) / \partial \ln \left(\varepsilon_{\mathrm{b}}\right)>0$, because $\alpha_{\mathrm{t} 1}+\alpha_{\mathrm{t} 2}+\alpha_{\mathrm{z} 1}+\alpha_{\mathrm{z} 2} \leq 1$ and $\mathrm{c} \leq 1$. Note that in the static model above, $\partial \ln \left(\mathrm{e}_{\mathrm{b}} / \mathrm{e}_{\mathrm{a}}\right) / \partial \ln \left(\varepsilon_{\mathrm{b}} / \varepsilon_{\mathrm{a}}\right)=1 /(1-\alpha \mathrm{c})>0$.
} 


$$
\partial \mathrm{R}_{2} / \partial \varepsilon_{\mathrm{a}}=\beta \mathrm{c}(1-\beta) \mathrm{e}_{\mathrm{b}} \mathrm{c}_{\mathrm{a}}{ }^{\mathrm{c}}\left[\left(\alpha_{\mathrm{t} 1}+\alpha_{\mathrm{z} 1}\right)-\left(\alpha_{\mathrm{t} 2}+\alpha_{\mathrm{z} 2}\right)\right]\left[\partial \ln \left(\mathrm{e}_{\mathrm{b}} / \mathrm{e}_{\mathrm{a}}\right) / \partial \ln \left(\varepsilon_{\mathrm{a}}\right)\right]\left(\mathrm{y}_{2}+\mathrm{w}_{2} \mathrm{~T}\right) / \varepsilon_{\mathrm{a}} \mathrm{D}^{2}
$$

Thus, the effect of the first child's endowment $\left(\varepsilon_{\mathrm{a}}\right)$ on resources devoted to second period human capital investment in children depends not only on whether parents compensate or reinforce endowments, but also on the difference between the sums of the human capital production elasticities in the two periods of childhood, $\left(\alpha_{t 1}+\alpha_{z 1}\right)$ $\left(\alpha_{t 2}+\alpha_{z 2}\right)$. If there are the same returns to scale within each period (say, 0.5$)$, this difference is zero and $\partial \mathrm{R}_{2} / \partial \varepsilon_{\mathrm{a}}=0$. This assumption is consistent with mother's time inputs having a higher elasticity when the child is young while goods inputs have a higher elasticity later in childhood. ${ }^{12}$ Because information on $\varepsilon_{\mathrm{b}}$ is not yet revealed, $\partial \mathrm{R}_{2} / \partial \varepsilon_{\mathrm{b}}=0$. Thus, $\mathrm{R}_{2}$ is exogenous under the assumption that returns to scale are the same within each period.

In most data however, $\mathrm{R}_{2}$ is not observed. At best, we observe total mother's time inputs to human capital investment in period $2, \mathrm{t}_{2 \mathrm{a}}+\mathrm{t}_{2 \mathrm{~b}}$. But it cannot be expressed simply in terms of $\mathrm{R}_{2}$. In particular,

$$
\left(\alpha_{\mathrm{t} 1}+\alpha_{\mathrm{z} 1}\right) \mathrm{t}_{2 \mathrm{~b}} / \alpha_{\mathrm{t} 1}+\left(\alpha_{\mathrm{t} 2}+\alpha_{\mathrm{z} 2}\right) \mathrm{t}_{2 \mathrm{a}} / \alpha_{\mathrm{t} 2}=\mathrm{R}_{2} / \mathrm{w}_{2}
$$

If, however, we make the stronger assumption that the respective production elasticities in the two stages of a child's life are proportional to each other (i.e., $\alpha_{k 2}=\lambda \alpha_{k 1}, \quad k=t, z, \quad$ with $\quad 0 \leq \lambda \leq 1, \quad$ where $\left.\quad\left(\alpha_{t 1}+\alpha_{z 1}\right) \leq 1 /(1+\lambda)\right)$, then $\quad t_{2 a}+t_{2 b}=$ $\alpha_{\mathrm{t} 1} \mathrm{R}_{2} /\left(\alpha_{\mathrm{t} 1}+\alpha_{\mathrm{z} 1}\right) \mathrm{w}_{2}$, and we can express $\mathrm{e}_{\mathrm{a}}$ and $\mathrm{e}_{\mathrm{b}}$ as functions of $\mathrm{t}_{2 \mathrm{a}}+\mathrm{t}_{2 \mathrm{~b}}$. Then

(6) $\partial\left(\mathrm{t}_{2 \mathrm{a}}+\mathrm{t}_{2 \mathrm{~b}}\right) / \partial \varepsilon_{\mathrm{a}}=(1-\lambda) \alpha_{\mathrm{t} 1} \beta \mathrm{c}(1-\beta) \mathrm{e}_{\mathrm{b}}{ }^{\mathrm{c}} \mathrm{e}_{\mathrm{a}}{ }^{\mathrm{c}}\left[\partial \ln \left(\mathrm{e}_{\mathrm{b}} / \mathrm{e}_{\mathrm{a}}\right) / \partial \ln \left(\varepsilon_{\mathrm{a}}\right)\right]\left(\mathrm{y}_{2}+\mathrm{w}_{2} \mathrm{~T}\right) / \varepsilon_{\mathrm{a}} \mathrm{D}^{2} /\left(\alpha_{\mathrm{t} 1}+\alpha_{\mathrm{z} 1}\right) \mathrm{w}_{2}$

Thus, equal production elasticities $(\lambda=1)$ in the two stages of a child's life are required to justify $\mathrm{t}_{1 \mathrm{a}}-\left(\mathrm{t}_{2 \mathrm{a}}+\mathrm{t}_{2 \mathrm{~b}}\right)$ as an exogenous explanatory variable, even when

\footnotetext{
${ }^{12}$ If $\alpha_{t 1}+\alpha_{21}>\alpha_{12}+\alpha_{22}$, a higher endowment for the first child would decrease (increase) the resources devoted to children's human capital investment in period $2\left(\mathrm{R}_{2}\right)$ if parents reinforce (compensate for) endowment differences, because we expect that $\partial \ln \left(\mathrm{e}_{\mathrm{b}} / \mathrm{e}_{\mathrm{a}}\right) / \partial \ln \left(\varepsilon_{\mathrm{a}}\right)<0$. At the same time, $\mathrm{t}_{2 \mathrm{a}} / \mathrm{t}_{2 \mathrm{~b}}$ would
} 
information about a child's endowments is not revealed until he/she is older. The reason is that parents can make compensating or reinforcing investments when endowments are revealed. Under these information revelation and production technology assumptions, the difference in amounts of the mother's time devoted to human capital investment when each child is in the second part of his/her childhood, $t_{2 a}+t_{2 b}-t_{3 b}$, is not independent of endowments as long as parents respond to endowments when they are revealed. ${ }^{13}$

\section{Data}

The preceding framework implies that estimation of the impact of parental employment patterns during childhood on the educational attainments of young adults requires data that provide longitudinal information on parents' fertility, marriage, and work. The data must also allow us to identify siblings whose information is needed in the estimation of the conditional demand functions in the presence of heterogeneity in parental preferences and technology. The data used in this analysis come from the first seven waves (1991-1997) of the British Household Panel Survey (BHPS), which has collected information on a nationally representative random sample of private households in Britain since 1991 and annually thereafter. ${ }^{14}$ We match young adults to (at least one of) their parents in at least one of the panel years. Once parents are identified, the BHPS provides a complete work history (collected in the 1993 wave), that makes it possible to construct the patterns of parental employment during the entire childhood of each young adult in the survey. For each young adult, we measure

\footnotetext{
increase (decrease) as a consequence of higher $\varepsilon_{\mathrm{a}}$ if parents reinforce (compensate for) endowments differences.

${ }^{13}$ When $\varepsilon_{b}$ is not revealed until the last period, $\partial \mathrm{R}_{3} / \partial \varepsilon_{\mathrm{b}}=\left[\mathrm{c} \beta(1-\beta)\left(\alpha_{\mathrm{t} 2}+\alpha_{\mathrm{z} 2}\right) \mathrm{e}_{\mathrm{b}}{ }^{\mathrm{c}} \mathrm{e}_{\mathrm{a}}{ }^{\mathrm{c}}\right]\left(\mathrm{y}_{3}+\mathrm{w}_{3} \mathrm{~T}\right) / \varepsilon_{\mathrm{b}} \mathrm{D}^{2}$.

${ }^{14}$ Detailed information on the BHPS can be obtained at http://www.iser.ac.uk/bhps/doc/index.html. A further description of the data used here can be found in Ermisch and Francesconi (2000).
} 
the length of time that his/her parents spent in paid work during three developmental stages, ages 0-5, 6-10 and 11-15, and for mothers we distinguish between time spent in part-time work and time spent in full-time work. ${ }^{15}$ The data also provide a complete fertility and marital history (collected in the 1992 wave) so that it is possible to identify siblings and half-siblings and determine the patterns of childhood family structure. ${ }^{16}$ The parent-child matching also permits measurement of other family background characteristics that would be unavailable otherwise (such as age of parents' at the young person's birth, parental education, and number of brothers and sisters).

The analysis is performed on four samples, two of which only allow for crosssectional estimates (i.e. across family comparisons). These estimates offer a useful benchmark for comparison with the existing literature. Our first sample (labeled as Main Sample or MS) consists of 1,026 individuals who: (i) are aged 18 or more and were born between 1970 and 1981; (ii) do not have serious disabilities; ${ }^{17}$ (iii) lived with their biological, adoptive or step parent(s) for at least one year during the first seven waves of the panel study; and (iv) have complete information on mother's employment patterns during childhood and other variables relating to her. We impose this last condition so that, by construction, we have full information on the key

\footnotetext{
${ }^{15}$ Ermisch and Francesconi (2000) further distinguish the first twelve months of the child's life within the first developmental stage. The parental employment (and family structure) effects of this first year on education are small and never significant. Since the results for the 0-5 stage are similar to the results for the 1-5 stage while the estimates for the other two developmental stages are unchanged, we present our results with only three developmental stages.

${ }^{16}$ The measure of family structure used in this paper is a dummy variable taking the value of one if the young adult spent time in a single-parent family during his/her childhood. This measure is broken down by the timing of the start of a spell in a single-parent family, distinguishing between the three child development stages defined above. Both childhood family structure and childhood parental employment do not suffer from the "window problem" discussed by Wolfe et al. (1996).
} 
variables for our analysis. Condition (i) is imposed because it is rare to obtain Alevels (our measure of educational attainment) before age 18, and also because it restricts the sample to a group of individuals with a comparable educational system. ${ }^{18}$ Condition (ii) rules out cases for which mother's employment patterns are arguably determined by children's endowments. Condition (iii) is needed to match data on family background from the parents' records to their child. It creates, however, the potential for sample selection bias if unobservable attributes affecting educational attainment also affect the chances of residence with parents. This is the reason why we present further evidence based on a Restricted Sample (RS), in which individuals from MS must be aged 16-17 when they live with their parent(s). ${ }^{19}$ Because 95 percent of the panel members live with their parents when aged 16-17, RS is likely to be a random sample. This sample consists of 647 individuals. Finally, the two samples used for estimates of the effect of parents' employment patterns on children's achievements based on sibling differences (i.e. within family comparisons) are obtained from the siblings present in the Main Sample (SMS) and from the siblings present in the Restricted Sample (SRS). In SMS there are 274 households with 2 or more siblings (or half-siblings) for a total of 599 individuals and a maximum of 381 sibling comparisons. In SRS we have 155 households with 2 or more siblings, totaling 326 individuals and 187 sibling comparisons.

\footnotetext{
${ }^{17}$ Serious disabilities are defined as being registered as a disabled person (either with Social Security or with a green card) and having any of the following health problems: sight problems, hearing problems, asthma, diabetes, epilepsy, and emotional disturbances. See Blau and Grossberg (1992) for a similar sample selection. As a result of such a selection we lose 10 individuals in our sample. We have performed the entire analysis also including those 10 disabled individuals and found remarkably similar results to those reported here.

${ }^{18}$ Those who completed their education in 1988 (born 1971-1972) were the first to study for the General Certificate of Secondary Education (GCSE) qualification; earlier cohorts would have studied for "O(Ordinary)-level" qualifications. For non-British readers, "A(Advanced)-level" corresponds to education beyond high school, but short of a university degree; GCSE and O-level qualifications roughly correspond to a high school diploma.
} 
Table 1 shows the means of all variables used in the analysis by estimating sample. To provide a meaningful comparison across samples the figures on the SMS and SRS are computed on all individuals rather than on sibling differences. Educational attainment of the child is defined as achieving an "A(Advanced)-level" qualification or higher qualification. ${ }^{20}$ For each young person, we take the highest educational level as that in the latest year in which we observe him/her in the panel. Table 1 indicates that the percentage of individuals who have achieved a highest qualification of at least $\mathrm{A}$ level is almost 62 percent in the main sample and 64 percent in SMS (63 and 67 percent in the younger RS and SRS). By construction, we have complete information about their mothers' childhood employment and the other background variables related to her for all young adults in our samples. But one in six people do not have a "father-figure" present during the panel period. When present, the father-figure is the natural father for the cases in which the family has remained intact, but he would be the stepfather in other cases. For short, we shall refer to the father-figures as "fathers". An additional one in six people do not have any information about their father's working patterns during childhood. This is either because the father was not present in the third wave of the BHPS, when the retrospective job history information was collected, or because we could not construct a complete work history over the young adult's childhood. ${ }^{21}$ As expected, fathers

\footnotetext{
${ }^{19}$ The age restriction on this sample implies that individuals were born between 1974 and 1981. The age range is then 16-24, while the age range in MS is 16-27.

${ }^{20}$ In addition to those who obtained a university degree, our measure of educational attainment includes also those with higher "vocational" qualifications, such as teaching and nursing qualifications, City and Guilds certificate, Higher Certificate/Diploma and University Diploma, many of whom probably did not obtain an A-level. Indeed, 19 percent of the young adults in MS (16 percent of those in RS) have these qualifications (that is, 30 percent of those who have achieved a highest qualification of at least A level). In 40 percent of the sibling pairs, one has a qualification of at least A-level and the other does not.

${ }^{21}$ Rather than dropping individuals with missing father or missing father's work history information from the analysis, we chose to maximise our sample size by retaining all individuals and indicating missing father or missing father's work information with two dummy variables. All variables with missing values have been replaced with zeros.
} 
spent a substantial fraction of time in the labour market. The average figures reported in square brackets of Table 1 are computed for children with fathers present and job history information available. These indicate that fathers worked on average 90 percent of the time during their children's childhood, or approximately 175 months over 192. This means about 1 month of non-employment in each of the 16 years of dependency of their child.

Mothers were, on average, in paid employment almost 96 months during childhood, that is, 50 percent of the first sixteen years of life of their children. Maternal employment and child's age are clearly positively related. Between the child's birth and the sixth birthday, mothers worked on average about 18 months in MS and RS and 16 months in SMS and SRS. During primary school years, their time in paid employment increased to about 30 months; and, finally, during their child's adolescence, they worked for 45 months. This picture does not significantly change if we confine our attention to mothers who were employed sometime at each development stage (the figures are reported in square brackets of Table 1). More than 60 percent of their time in paid employment was in part-time work, but the employment gradient with child's age is as steep in part-time work as it is in full-time work.

Nearly 48 percent of young adults in each sample are women. The average age of the young adults in MS and SMS is just above 21, and slightly less than 20 in RS and SRS. The average year of birth is 1975 for people in the main sample and 1976 for those in the restricted sample. ${ }^{22}$ About one-fourth of the people in MS and RS

\footnotetext{
${ }^{22}$ Ermisch and Francesconi (2000) document that the absolute age differences between siblings in SMS and SRS are on average of 3.08 and 2.72 years, respectively. Approximately 75 percent and 82 percent of the age differences are less than 4 years in SMS and SRS respectively, while only 15 percent and 7 percent of the age differences are above 5 years. Interestingly, we observe 7 and 5 twin births in SMS
} 
experienced life in a single-parent family; that is, either their mother's partnership dissolved before they reached age 16, or they were born outside a live-in partnership. Of the children who spent some time in a single parent family, 45 percent did so below the age of 6. In SMS and SRS the proportion of young adults who experienced life in a single parent family is lower, and approximately 20 percent. But again, of those who spent time in a single parent family, almost 45 percent did so by age 6 . More than one-quarter of the mothers and one-third of the fathers of these young adults had no academic qualification, while 9-10 percent of mothers and fathers held a university degree. On average, mothers gave birth at age 26 , when fathers were approximately 2 years older. Approximately 7 percent of the young people were an only child, while 40 percent were firstborn. They had an average of 1-2 brothers and sisters.

\section{Econometric model}

Consider the model presented in Section 2.2 when information about the child's endowment is not immediately revealed to the parents (i.e., it becomes known only during the second part of the child's childhood). If $\alpha_{\mathrm{k} 1}=\alpha_{\mathrm{k} 2}(\mathrm{k}=\mathrm{t}, \mathrm{z})$ the following equation is an approximation to the difference between the conditional demand functions for each sibling's earning capacity (e.g., the difference in educational attainment):

$$
\mathrm{e}_{\mathrm{a}}-\mathrm{e}_{\mathrm{b}}=\delta_{0}+\delta_{1}\left[\left(\mathrm{t}_{2 \mathrm{a}}+\mathrm{t}_{2 \mathrm{~b}}\right)-\mathrm{t}_{1 \mathrm{a}}\right]+\delta_{2}\left(\mathbf{X}_{\mathrm{a}}-\mathbf{X}_{\mathrm{b}}\right)+\varepsilon_{\mathrm{a}}-\varepsilon_{\mathrm{b}}
$$

where the mother's time input into human capital production in each period has been replaced by its complement, mother's employment time, and dynamic responses in the

and SRS respectively, corresponding to a twinning probability of 0.0088 and 0.0098 , which compares favourably with the statistics reported in Ashenfelter and Rouse (1999). 
third period have been "substituted out". Thus, $\delta_{1}$ reflects preference parameters, expectations about future incomes, prices and wages and realizations of these, as well as household production technology. It measures the full impact of $\left(t_{2 a}+t_{2 b}\right)-t_{1 a}$ on $e_{a^{-}}$ $\mathrm{e}_{\mathrm{b}}$. The vector $\mathbf{X}$ denotes a set of individual characteristics, which, in our estimation, are: the young adult's gender, age, experience of life in a single-parent family at each developmental stage, age of the mother and father at the child's birth, whether or not he/she is the firstborn, whether or not there is a missing father figure, and whether there is no information on the father's employment patterns.

The variables $t_{1 a}$ and $t_{2 a}+t_{2 b}$ in specification (7) serve as sufficient statistics for the effects of $\mathrm{w}_{1}, \mathrm{w}_{2}, \mathrm{p}_{1}, \mathrm{p}_{2}, \mathrm{y}_{1}$ and $\mathrm{y}_{2}$ on human capital investment in each child when he/she is "young"; their effects work through $\left(t_{2 a}+t_{2 b}\right)-t_{1 a}$. While equation (7) approximates a complex reduced form expression, if $\alpha_{\mathrm{k} 1}=\alpha_{\mathrm{k} 2}(\mathrm{k}=\mathrm{t}, \mathrm{z})$ we can interpret $\delta_{1}$ as reflecting the effect of the amount of mother's time allocated to her children's human capital investment when they were of pre-school age on their subsequent educational attainments, leading us to expect $\delta_{1}$ to be negative. In other words, this is analogous to the special case of the static model in equation (2) above, in which the coefficient of $\ln \left(\mathrm{t}_{\mathrm{a}}+\mathrm{t}_{\mathrm{b}}\right)$ is $\alpha$, but now $\delta_{1}$ partly reflects preferences, expectations and realizations of incomes, prices and wages in the dynamic model. The negative $\delta_{1}$ means, for example, that, for a constant mother's wage and price of child investment goods, higher father's or other income in the first period $\left(\mathrm{y}_{1}\right)$ relative to that in the second period $\left(\mathrm{y}_{2}\right)$ increases the educational attainment of the first child relative to that of the second child. ${ }^{23}$

${ }^{23}$ A negative $\delta_{1}$ also implies that the children from families with higher full income throughout their childhood will have more invested in their human capital and have higher educational attainments and lifetime earnings. As we have not estimated the parameters that allow us to gauge the impacts of the 
Application of ordinary least squares (OLS) to (7) provides a consistent estimate of $\delta_{1}$ when $\alpha_{k 1}=\alpha_{k 2}(k=t, z)$, or, equivalently, when $\lambda=1$ in (6), because the difference between the amounts of the mother's time devoted to human capital investment when each child is "young" can be taken as exogenous in equation (7) in this case. If, however, $\lambda \neq 1$, an OLS estimate would be a biased estimate of $\delta_{1}$, and the direction of the bias depends on $\lambda$ and c. Suppose $\lambda<1$. Then, from equation (6), an OLS estimate of $\delta_{1}$ would overstate the size of $\delta_{1}$ if parents reinforce endowment differences and understate it if they compensate for differences in endowments. This is because, when $\lambda<1$, parents respond to a higher $\varepsilon_{\mathrm{a}}$ by increasing employment time in period 2 (i.e. reducing $t_{2 a}+t_{2 b}$ ) if they act to reinforce endowments; thus, mothers with high $\mathrm{t}_{2 \mathrm{a}}+\mathrm{t}_{2 \mathrm{~b}}$ tend to have first children with low $\varepsilon_{\mathrm{a}}$. Conversely, when parents act to compensate for endowment differences, mothers with high $t_{2 \mathrm{a}}+\mathrm{t}_{2 \mathrm{~b}}$ tend to have first children with high $\varepsilon_{\mathrm{a} \cdot}{ }^{24}$

In a more complex model, in which the allocation of more of the mother's time to paid employment when the child is a pre-schooler increases her wage in the future, the full effects of the mother's time allocation when the child is a pre-schooler are ambiguous. In such a model, the direct effect on human capital investment of spending more time in paid employment when the child is a pre-schooler, which lowers educational attainments, may be offset by the effect of higher full family income later in childhood if goods inputs are sufficiently more productive in human capital investment than mother's time inputs when a child is older.

mother's wage, price of child investment goods and full family income on the mother's time allocation, we are not able to assess the quantitative impact of them on children's educational attainments.

${ }^{24}$ As equation (5) shows, if the respective production elasticities in the two stages of a child's life are not proportional, there is not a clear mapping between $R_{2}$ and $t_{2 a}+t_{2 b}$, making interpretation of the regression coefficient $\delta_{1}$ more difficult. 
The static model of Section 2.1 makes it clear that cross-sectional estimates of the relationship between parental employment during childhood and children's later educational achievements are likely to be biased. This is because the resources devoted to human capital investment in children, $\mathrm{R}$, are not generally independent of their endowments, $\varepsilon_{\mathrm{a}}$ and $\varepsilon_{\mathrm{b}}$ (and even if they are, there is likely to be heterogeneity in w/p and production technology). Most of our knowledge of the association between parents' employment and children's educational attainments is, however, based on evidence obtained from cross-sectional estimates. We shall, therefore, present evidence on such estimates as well.

In the empirical analysis, we estimate logit regressions on both the crosssectional samples (MS and RS) and the sibling samples (SMS and SRS). In the sibling samples, we sort siblings so that the sibling with higher education is listed first. Correspondingly, the dependent variable takes the value of unity if one of the siblings has an A-level or above and the other does not, and zero otherwise. ${ }^{25}$ All figures are marginal effects and should be interpreted as deviations from the corresponding baseline probabilities.

\section{Results}

\subsection{Preferred estimates}

Our dynamic model suggests that a causal interpretation of the relationship between parental employment during childhood and educational attainment of children as young adults relies on rather strong assumptions, even if sibling difference estimates are used. The assumption that parents do not know (or have limited information

\footnotetext{
${ }^{25}$ Because of the non-random sorting of siblings, a constant term is included in the differenced education equation (Ashenfelter and Rouse 1998).
} 
about) their children's idiosyncratic endowments is more likely to be true when the child is very young (e.g., in pre-school years). Thus, our preferred estimates are those that only use parents' employment patterns (and family structure) in the first of the three developmental stages, (i.e. when the child is aged 0-5) as the parental employment variables. Information on the subsequent developmental stages is dropped from the estimation.

The parameter estimates associated with the parental employment variables are reported in Table $2 .^{26}$ There is strong evidence from the sibling difference estimates of an adverse effect of mother's full-time employment on her children's probability of achieving A level or more. The effect is measured with precision, and its point estimate ranges between a 7 and 9 percentage point lower probability, depending on the estimating sample. A negative effect is also detected by the cross-sectional estimates but it is weaker and not statistically significant. There is also evidence of a negative effect on education of the mother's part-time employment during the child's first five years of life. But this effect is smaller in magnitude, ranging from a 3 to 6 percentage point lower probability of achieving A-level or more, and it is less precisely estimated. Interestingly, the effect of father's employment is also negative and around 4 percentage points in the case of SMS. The positive cross-sectional relationship between child's education and father's time in paid work is likely to pick up the positive correlation between children's educational attainment and father's endowment, which, in turn, is positively correlated with his employment patterns. Our conditional demand framework provides a straightforward economic interpretation of these results. A higher full family income when the child was aged 0-5 increases

\footnotetext{
${ }^{26}$ The Appendix Table A1 contains the estimates of the parameters for all other variables used in the analysis. A discussion of these estimates can be found in Ermisch and Francesconi (2000).
} 
his/her educational attainments, because this increases parents' time allocated to human capital investment in children. Given full family income, a higher mother's or father's wage in the first five years of life of their child reduces the child's educational achievements, because more time is allocated to the labour market.

How credible is the assumption that parents do not know (or have limited information on) their children's idiosyncratic endowments? Following the suggestion by Rosenzweig and Wolpin (2000), we provide supplemental empirical information needed to support this identifying assumption. Before doing so, we show that parents' labour market behaviour is correlated with children's endowments when the parents are aware of them. In 1991, the BHPS asked mothers whether any of her children has serious health problems. ${ }^{27}$ For all the 1,382 mothers with available information we distinguish three labour market states: out of the labour force, part-time employment (working fewer than 30 hours per week) and full-time employment (working 30 or more hours per week). We group children with limiting health conditions by age, according to the three developmental stages used above: 0-5, 6-10, 11-15. Table 3 reports the multinomial logit estimates of mother's labour force participation, with the omitted category being out of the labour force. The estimates are reported for two specifications: the first includes the dummy variables indicating the presence of children with health problems by age only, while the second includes also a standard set of regressors such as mother's education, part-time and full-time experience, number of children by age and partner's earnings. The estimates obtained from both specifications clearly reveal that the presence of children aged 10 or less who have limiting health conditions is associated with a lower likelihood of mother's full-time 
employment. The presence of children with poor health status, however, does not affect the probability of part-time employment (according the estimates of specification (2)) nor does it affect the probability of full-time employment provided that the child is an adolescent.

Turning to our assumption about knowledge of children's endowments, we first present evidence that parents do make mistakes in assessing their infant's and children's endowments or they are not fully aware of them. We then argue that parental inaccuracies (and unawareness) tend to decline as children get older. Parents' ability to assess their own children's endowments is partly related to the feedback received from children themselves. Parents seem to be most accurate when their children's performance falls at an extreme, either very high or very low, because of the clarity of the feedback that they receive (Heriot and Schmickel 1967). But parents of children that fall in between such extremes are likely to be more inaccurate. Frankenburg et al. (1976) screen a sample of 1,141 infants and children and find that 30 children have major neuromotor abnormalities, mental deficiency or a combination of both, 106 have minor abnormalities, and 1,005 are normal. Those with minor problems are possibly the "in-between" children, because their abnormalities are clinically questionable and, in many circumstances, temporary. Parents are also asked to complete a diagnostic examination for their own children. A comparison of the examination performed by the parents with that performed by the physicians shows that, among children with major deficiencies, four (or 13 percent) are missed, 46

\footnotetext{
${ }^{27}$ The exact question is: "Does your child (do any of your children) under 16 have any health conditions that limit his/her normal childhood activities?" Almost 15 percent of mothers' valid answers (244 out of 1640) is yes.
} 
percent of those with minor problems are undetected, and 27 percent of those who are normal are reported to have problems by their parents. ${ }^{28}$

In the child psychology literature, Hunt (1966) formulates a theory by which parents who do not know their children's abilities are more likely to confront them with an environment that poses either boring under-matches or distressing overmatches. Because parents who know their children's abilities are less likely to do so, the correlation between the parental inaccuracy and children's level of development is expected to be negative. The validation of this theory, therefore, lies entirely on the fact that some parents have a limited knowledge of their infants' abilities and interests. In testing this theory, Hunt and Paraskevopoulos (1980) find that mothers largely overestimate the cognitive and intellectual abilities of their own children. In general, overestimation appears to be common also in parents' competency to judge children's performance in post-infancy years, while there is evidence of a tendency toward underestimation in the case of infancy items (see Miller 1988 for a survey).

One of the most compelling arguments to support our information revelation assumption is perhaps given by the complexity of many disorders such as autism, that parents (and physicians) find hard to observe. Approximately one-half of autistic children develop normally until somewhere between 18 to 36 months of age, then autistic symptoms (e.g., self-stimulatory behaviour, self-injury, sleeping and eating problems, attention deficits, and hyper-/hypo-activity) begin to emerge (Edelson 1999). Similarly, children with Landau-Kleffner Syndrome exhibit autistic behaviours quite late: they appear, in fact, to be normal until sometime between ages 3 and 7 .

\footnotetext{
${ }^{28}$ Knobloch et al. (1979) report overall higher levels of parental accuracy in a sample of 526 infants screened at 28 weeks of age. But, again, parental underscreening of children with minor abnormalities
} 
Parents, however, accumulate information about their children as they grow older. This process is likely to reduce parental inaccuracies about their children's endowments. Entwisle and Hayduk (1981) do find that parents have increasingly realistic academic expectations (lower inaccuracy) as children progress through school, presumably because of the frequency and clarity of the cumulative feedback that the parents receive concerning their children's ability. There is evidence of this phenomenon also in the case of physically handicapped children (Anton and Dindia 1984). These findings therefore support the assumption that parents know their children's endowments later in their childhood (see below).

\subsection{The effect of parental employment over the entire childhood}

Most of the results presented in Table 2 emerge also when parental employment patterns over the other two developmental stages are included in estimation. As discussed in the previous subsection, this inclusion, however, makes the assumption that parents have a limited knowledge of their children's endowments less credible. Table 4 contains the parameter estimates associated with parental employment. On the basis of the sibling comparisons in the main sample (SMS), the effect is about a 3percentage point lower probability of achieving at least A level from an additional year of mother's part-time employment when her child was aged $0-5$. There is an 8 percentage point lower probability from an additional year of mother's full-time employment at these pre-school ages. The corresponding estimates obtained from SRS are a 6 percentage point and an 11 percentage point lower probability. From the sibling comparisons, the adverse effect of father's employment in pre-school years is around 3-4 percentage points, but it is not well determined. Similarly, the crosspercent and over-reporting of normal children is 6 percent. 
sectional estimates of the mother's (part-time and full-time) employment in the first developmental stage are small and never statistically significant, while the crosssectional estimates of the father's employment are positive and significant. These results may arise because the cross-sectional estimates fail to control adequately for children's endowment heterogeneity and family background. Interestingly, the SMS estimates suggest that one year more full-time employment when the child was aged 6-10 increases the probability of achieving A-level or higher by 8 percentage points. This large and significant effect is not, however, replicated by the SRS estimate (which is still positive but statistically insignificant). Thus, there may be an offset to the negative impact of full-time employment when the child was a pre-schooler for women who continued to work full-time when the child was aged 6-10. ${ }^{29}$

\section{Conclusions}

This paper has presented a theoretical framework that provides the conditions under which we can give a causal interpretation to the association between childhood parental employment and subsequent education of children as young adults. In an environment in which parental preferences are separable in own consumption and children's well-being, estimation is complicated by endowment heterogeneity and by the fact that parents may compensate or reinforce children's endowments relevant to educational attainment. While a sibling difference estimate strategy may be useful to eliminate endowment heterogeneity that is common across siblings, it is generally not sufficient to provide a consistent estimate of the parameter of interest. That rests on two stronger assumptions. First, the idiosyncratic endowments of children are not

\footnotetext{
${ }^{29}$ There is, indeed, a large amount of persistence in full-time employment: the correlation coefficient between months in full-time employment when the child was aged 0-5 and when he/she was aged 6-10
} 
revealed to parents at birth (it takes time before parents fully know their children's endowments). Second, the parents' time and good elasticities of the children's human capital production function do not vary across ages of the child nor across siblings.

The empirical analysis uses data from various samples of young people drawn from the British Household Panel Survey. There is a negative and significant effect on the child's educational attainment as a young adult of the mother's full-time employment when the child was aged 0-5. The effect of mother's part-time employment is also negative but smaller and less well determined. Similarly, the effect of father's employment is small, not always precisely estimated but again negative. The negative effects of mother's part-time work and, particularly, of mother's full-time work, persist when we include parents' employment patterns over the entire childhood period. In the context of our conditional demand function framework, these results suggest that a higher full family income increases the educational attainment of children, and given full family income, a higher mother's or father's wage reduces their children's educational attainment. 


\section{References}

Anton, B.S. and G. Dindia (1984), "Parental perception of cognitive abilities of children with cerebral palsy." Psychological Reports, 54, 98-990.

Ashenfelter, O. and C. Rouse (1998), "Income, schooling, and ability: Evidence from a new sample of identical twins." Quarterly Journal of Economics, 113(1), 253-284.

Ashenfelter, O. and C. Rouse (1999), "The payoff to education." Unpublished paper presented at the IZA-CEPR European Summer Symposium in Labour Economics, Ammersee (Germany), September.

Becker, G.S. (1965), “A theory of the allocation of time.” Economic Journal, 75, 493517.

Becker, G.S. (1981), A treatise on the family. Cambridge: Harvard University Press.

Becker, G.S. and N. Tomes (1976), "Child endowments and the quantity and quality of children." Journal of Political Economy, 84, no. 4, pt. 2, S143-S162.

Becker, G.S. and N. Tomes (1986), "Human capital and the rise and fall of families." Journal of Labor Economics, 4(3), S1-S39.

Behrman, J.R., R. Pollak and P. Taubman (1982), Parental preferences and provision for progeny, Journal of Political Economy, 90(1), 52-73.

Blau, D.M., D.K. Guilkey, and B.M. Popkin (1996), "Infant Health and the Labor Supply of Mothers." Journal of Human Resources, 31(1), 90-139.

Blau, F.D., and A.J. Grossberg (1992), "Maternal labour supply and children's cognitive development." Review of Economics and Statistics, 74, 474-481.

Blundell, R.W. and I. Walker (1986), "A life cycle consistent empirical model of labour supply using cross section data." Review of Economic Studies, 53, 539558.

Currie, J. and N. Cole (1993), "Welfare and child health: The link between AFDC participation and birth weight." American Economic Review, 83, 971-985.

Duncan, G.J., J. Teachman and W.J. Yeung (1997), "Childhood family income and completed schooling: Results from sibling models." Unpublished paper, Northwestern University, Institute for Policy Research, July.

Duncan, G.J., W.J. Yeung, J. Brooks-Gunn and J. Smith (1998), "How much does childhood poverty affect the life chances of children?" American Sociological Review, 63, 406-423.

Entwisle, D.R. and L.A. Hayduk (1981), "Academic expectations and the school attainment of young children." Sociology of Education, 54, 34-50.

Edelson, S.M. (1999), Overview of autism. Center for the Study of Autism, Salem, Oregon, http://www.autism.org/overview.html.

Ermisch, J. and M. Francesconi (2000), The effects of parents' employment on children's outcomes. York: Joseph Rowntree Foundation.

Frankenburg, W.K., W.J. van Doorninck, T.N. Liddell and N.P. Dick (1976), "The Denver prescreening developmental questionnaire." Pediatrics, 57, 744-753. 
Gregg, P. and S. Machin (1998), "Child development and success or failure in the youth labour market." Centre for Economic Performance Discussion Paper No. 397, London School of Economics.

Harvey, E. (1999), "Short-term and long-term effects of early parental employment on children of the National Longitudinal Survey of Youth." Developmental Psychology, 35, 445-459.

Haveman, R. and B. Wolfe (1995), "The determinants of children's attainments: a review of methods and findings." Journal of Economic Literature, 33, 18291878.

Hanushek, E.A. (1992), "The trade-off between child quantity and quality." Journal of Political Economy, 100 (1), 84-117.

Heriot, J.T. and G.A. Schmickel (1967), "Maternal estimates of IQ in children evaluated for learning potential." American Journal of Mental Deficiency, 71, 920-924.

Hunt, J. McV. (1966), "Toward a theory of guided learning in development." In R.J. Ojemann and K. Pritchett (eds.), Giving emphasis to guided learning. Cleveland, Oh.: Educational Research Council.

Hunt, J. McV. and J. Paraskevopoulos (1980), "Children's psychological development as a function of the accuracy of their mothers' knowledge of their abilities." Journal of Genetic Psychology, 136, 285-198.

Joshi, H. and G. Verropoulou (2000), Maternal employment and child outcomes. Smith Institute Report.

Kiernan, K.E. (1997), "The legacy of parental divorce: social, economic and demographic experiences in adulthood." Centre for Analysis of Social Exclusion, London School of Economics, CASEpaper 1.

Knobloch, H., F. Stevens, A. Malone, P. Ellison and H. Risemberg (1979), "The validity of parental reporting of infant development." Pediatrics, 63, 872-878.

Leibowitz, A. (1974), "Home investment in children." Journal of Political Economy, 82(2), pt. 2, S111-S131.

Michael, R.T. (1973), "Education in nonmarket production." Journal of Political Economy, 81, 306-327.

Miller, S.A. (1988), “Parents' beliefs about children's cognitive development." Child Development, 59, 259-285.

Mulligan, C.B. (1997), Parental priorities and economic inequality. Chicago: University of Chicago Press.

Pollak, R. (1971), Conditional demand functions and the implications of separable utility, Southern Economic Journal 37, 423-433.

Rosenzweig, M.R. (1986), "Birth spacing and sibling inequality: Asymmetric information with the household." International Economic Review, 27(1), 55776. 
Rosenzweig, M.R. and T.P. Schultz (1983), "Estimating a household production function: Heterogeneity, the demand for health inputs, and their effects on birth weight." Journal of Political Economy, 91(5), 723-746.

Rosenzweig, M.R. and K.I. Wolpin (1988), "Heterogeneity, intrafamily distribution and child health." Journal of Human Resources, 23, 437-461.

Rosenzweig, M.R. and K.I. Wolpin (1995), "Sisters, siblings, and mothers: the effect of teen-age childbearing on birth outcomes in a dynamic family context." Econometrica, 63, 303-326.

Rosenzweig, M.R. and K.I. Wolpin (2000), "Natural 'natural experiments' in economics." Journal of Economic Literature, forthcoming.

Strauss, J. (1990), "Households, communities and preschool children's nutrition outcomes: Evidence from rural Cote d'Ivoire." Economic Development and Cultural Change, 38, 231-261.

Wolfe, B. R. Haveman, D. Ginther and C.B. An (1996), "The 'window problem' in studies of children's attainments: A methodological exploration." Journal of the American Statistical Association, 91, 970-982. 
Table 1: Means of variables used in analysis

\begin{tabular}{|c|c|c|c|c|}
\hline \multirow[b]{2}{*}{ Variable } & \multicolumn{4}{|c|}{ Estimating sample } \\
\hline & MS & $\mathrm{RS}$ & SMS & SRS \\
\hline \multicolumn{5}{|l|}{ Dependent variable } \\
\hline A level or more & 0.617 & 0.629 & 0.641 & 0.665 \\
\hline \multicolumn{5}{|l|}{ Parental work variables } \\
\hline \multicolumn{5}{|l|}{ Mother's work: ${ }^{\mathrm{a}}$} \\
\hline child aged 0-5 (years) & $\begin{array}{c}1.607 \\
{[2.617]}\end{array}$ & $\begin{array}{c}1.569 \\
{[2.531]}\end{array}$ & $\begin{array}{c}1.405 \\
{[2.528]}\end{array}$ & $\begin{array}{c}1.255 \\
{[2.261]}\end{array}$ \\
\hline \multirow[t]{2}{*}{ child aged 6-10 (years) } & 2.581 & 2.554 & 2.430 & 2.416 \\
\hline & [3.134] & [3.060] & [2.996] & [2.917] \\
\hline \multirow[t]{2}{*}{ child aged 11-15 (years) } & 3.548 & 3.593 & 3.569 & 3.798 \\
\hline & {$[3.788]$} & [3.799] & [3.732] & [3.857] \\
\hline \multicolumn{5}{|l|}{ Mother's part-time work: ${ }^{\mathrm{a}}$} \\
\hline \multirow[t]{2}{*}{ child aged 0-5 (years) } & 0.952 & 0.973 & 0.987 & 0.921 \\
\hline & {$[2.331]$} & [2.359] & [2.355] & [2.327] \\
\hline \multirow[t]{2}{*}{ child aged 6-10 (years) } & 1.625 & 1.598 & 1.678 & 1.706 \\
\hline & [3.009] & {$[2.930]$} & [2.933] & [2.867] \\
\hline \multirow[t]{2}{*}{ child aged 11-15 (years) } & 2.093 & 2.123 & 2.231 & 2.471 \\
\hline & [3.808] & [3.816] & [3.776] & [3.891] \\
\hline \multicolumn{5}{|l|}{ Mother's full-time work: ${ }^{\mathrm{a}}$} \\
\hline \multirow[t]{2}{*}{ child aged 0-5 (years) } & 0.655 & 0.596 & 0.419 & 0.334 \\
\hline & {$[2.584]$} & {$[2.280]$} & {$[2.365]$} & [2.115] \\
\hline \multirow[t]{2}{*}{ child aged 6-10 (years) } & 0.957 & 0.956 & 0.751 & 0.710 \\
\hline & [3.146] & [3.076] & [2.831] & [2.754] \\
\hline \multirow[t]{2}{*}{ child aged 11-15 (years) } & 1.455 & 1.470 & 1.339 & 1.327 \\
\hline & {$[3.563]$} & [3.602] & [3.349] & [3.547] \\
\hline \multicolumn{5}{|l|}{ Father's work: ${ }^{\mathrm{a}}$} \\
\hline \multirow[t]{2}{*}{ child aged 0-5 (years) } & 3.630 & 3.612 & 3.770 & 3.643 \\
\hline & {$[5.413]$} & {$[5.398]$} & {$[5.462]$} & [5.549] \\
\hline \multirow[t]{2}{*}{ child aged 6-10 (years) } & 3.064 & 3.052 & 3.162 & 3.034 \\
\hline & [4.569] & [4.561] & [4.594] & [4.617] \\
\hline \multirow[t]{2}{*}{ child aged 11-15 (years) } & 3.095 & 3.078 & 3.175 & 3.048 \\
\hline & [4.615] & [4.599] & [4.612] & [4.644] \\
\hline \multicolumn{5}{|l|}{ Other variables } \\
\hline Age & 22.285 & 20.821 & 22.259 & 20.902 \\
\hline Female & 0.470 & 0.477 & 0.467 & 0.472 \\
\hline Year of birth -1900 & 74.729 & 76.454 & & \\
\hline \multicolumn{5}{|l|}{ Ever in single-parent family: } \\
\hline child aged $1-5$ & 0.107 & 0.111 & 0.073 & 0.080 \\
\hline child aged 6-10 & 0.078 & 0.085 & 0.068 & 0.061 \\
\hline child aged $11-15$ & 0.049 & 0.045 & 0.050 & 0.052 \\
\hline Age of mother at birth $\leq 21$ & 0.102 & 0.094 & 0.097 & 0.098 \\
\hline Age of mother at birth $\geq 35$ & 0.037 & 0.019 & 0.015 & 0.015 \\
\hline Age of mother at birth & 26.341 & 26.400 & 26.070 & 26.220 \\
\hline
\end{tabular}


Age of father at birth $\leq 21$

0.056

0.051

0.045

0.049

Age of father at birth $\geq 37$

28.698

0.051

0.042

0.034

Age of father at birth ${ }^{\mathrm{b}}$

0.859

28.637

28.477

28.301

Number of brothers

0.718

0.869

Number of sisters

0.450

0.708

Firstborn

0.070

0.421

0.411

Only child

Mother's education:

No qualification (base)

0.

0.062

Less than $\mathrm{O}$ level

0.117

0.

O level

0.222

0.114

A level

0.072

0.224

Higher vocational quals.

0.203

0.076

Higher qualification

0.081

0.221

0.088

Father's education:

No qualification (base) ${ }^{c}$

0.

0 .

Less than O level

$0.069 \quad 0.059$

O level

0.160

0.159

A level

0.095

0.107

Higher vocational quals.

0.230

0.233

Higher qualification

0.085

0.094

Father is missing (1=yes)

0.166

0.162

0.150

0.156

Information on father's work

is missing (1=yes)

0.329

0.331

0.311

0.344

N

1,026

647

599

326

Note: Figures in SMS and SRS are computed on levels (rather than sibling pairs). $\mathrm{N}$ is the number of sample-specific observations.

${ }^{\text {a }}$ Computed on all cases. Values computed only on cases with working mother or nonmissing father are in square brackets.

${ }^{\mathrm{b}}$ Computed only on cases with nonmissing father. The base category (age of father at birth is between 22 and 36) contains also cases with missing father information.

${ }^{\mathrm{c}}$ Includes cases with missing father. 
Table 2: Effects on the probability of achieving A level or more of the time parents worked when the child was aged 0-5 (Absolute ratios of coefficient to standard error are shown in parentheses)

\begin{tabular}{|c|c|c|c|c|}
\hline \multirow[b]{2}{*}{ Child aged $0-5$} & \multicolumn{2}{|c|}{$\begin{array}{c}\text { Cross-sectional } \\
\text { estimates }\end{array}$} & \multicolumn{2}{|c|}{$\begin{array}{c}\text { Sibling difference } \\
\text { estimates }\end{array}$} \\
\hline & MS & $\mathrm{RS}$ & SMS & SRS \\
\hline Baseline & 0.617 & 0.629 & 0.641 & 0.662 \\
\hline Mother's part-time employment & $\begin{array}{l}-0.003 \\
(0.299)\end{array}$ & $\begin{array}{l}-0.004 \\
(0.309)\end{array}$ & $\begin{array}{l}-0.031 \\
(1.872)\end{array}$ & $\begin{array}{l}-0.059 \\
(1.732)\end{array}$ \\
\hline Mother's full-time employment & $\begin{array}{l}-0.014 \\
(0.893)\end{array}$ & $\begin{array}{l}-0.024 \\
(1.060)\end{array}$ & $\begin{array}{l}-0.074 \\
(2.888)\end{array}$ & $\begin{array}{l}-0.086 \\
(2.409)\end{array}$ \\
\hline Father's employment & $\begin{array}{l}0.033 \\
(2.175)\end{array}$ & $\begin{array}{c}0.047 \\
(2.611)\end{array}$ & $\begin{array}{l}-0.042 \\
(2.055)\end{array}$ & $\begin{array}{l}-0.033 \\
(1.512)\end{array}$ \\
\hline Log likelihood & -608 & -365 & -235 & -109 \\
\hline$N$ & 1,026 & 647 & 381 & 187 \\
\hline \multicolumn{5}{|c|}{$\begin{array}{l}\text { Note: MS = main sample; RS = restricted sample; SMS = siblings from main sample; SRS = } \\
\text { siblings from restricted sample. Figures are marginal effects obtained from logit regressions. } \\
\text { Estimated standard errors account for arbitrary forms of correlation within siblings or half- } \\
\text { siblings. } N \text { is number of individuals in MS and RS, and number of siblings differences in } \\
\text { SMS and SRS. Other variables included in the regressions performed with MS and RS are: } \\
\text { gender, cohort, seven age dummies, dummies for firstborn and only child, ever lived in a } \\
\text { single parent family in the first developmental stage, number of brothers and sisters, age of } \\
\text { mother at child's birth (two dummy variables), age of father at birth (two dummy variables), } \\
\text { mother's education (five dummy variables), father's education (five dummy variables), } \\
\text { dummy variables for missing father and missing father's work history information, and a } \\
\text { constant. Other variables included in the regressions performed with SMS and SRS are the } \\
\text { sibling differences in: age, gender, firstborn, ever lived in a single parent family in the first } \\
\text { developmental stage, mother's age at birth was } 21 \text { or less, mother's age at birth was } 35 \text { or } \\
\text { more, father's age at birth was } 21 \text { or less, father's age at birth was } 37 \text { or more, missing father } \\
\text { and missing father's history. A constant term is also included because of non-random sorting } \\
\text { of siblings. }\end{array}$} \\
\hline
\end{tabular}


Table 3: Multinomial logit estimates of children having any limiting health problem on the mother's labour force status, by specification $(N=1,382)$

\begin{tabular}{cccccc}
\hline & \multicolumn{2}{c}{ Specification (1) } & & \multicolumn{2}{c}{ Specification (2) } \\
\cline { 2 - 3 } \cline { 5 - 6 } & Part-time & Full-time & & Part-time & Full-time \\
employment & employment & & employment & employment \\
\hline
\end{tabular}

Child who has health problems is aged:

\begin{tabular}{lcccc}
$0-5$ & -0.412 & -1.731 & -0.168 & -1.683 \\
& $(1.510)$ & $(4.166)$ & $(0.532)$ & $(3.756)$ \\
$6-10$ & -0.140 & -1.167 & -0.061 & -0.845 \\
& $(0.526)$ & $(3.319)$ & $(0.197)$ & $(2.176)$ \\
$11-15$ & 0.634 & 0.066 & 0.314 & 0.069 \\
& $(2.085)$ & $(0.201)$ & $(0.867)$ & $(0.177)$ \\
Log likelihood & \multicolumn{2}{c}{$-1,483$} & & \multicolumn{2}{c}{$-1,222$}
\end{tabular}

Note: Source: BHPS, 1991. $N$ is the number of mothers. Absolute values of asymptotic $t$-ratios are in parentheses. Specification (1) does not include any other regressor. Specification (2) includes variables for the mother's age group, race, marital status, position in the partner's earnings distribution, housing tenure, education, region of residence, quartic polynomials in full-time and part-time experience, her mother's and father's occupation when she was aged 14, dummy variables for missing information on her mother's and father's occupation, a dummy variable for having lived with both parents up to age 16, a dummy variable for missing information on childhood family structure, number of children by age group, dummy variable for having more than one child with health problems, local unemployment rate (geographic units are 306 travel-to-work areas), and a constant. 
Table 4: Effects of childhood maternal time in part-time and full-time employment and paternal time in employment on the probability of achieving A level or more by child developmental stage (Absolute ratios of coefficient to standard error are shown in parentheses)

\begin{tabular}{|c|c|c|}
\hline $\begin{array}{l}\text { Time of maternal employment } \\
\text { by child developmental stage }\end{array}$ & $\begin{array}{l}\text { Cross-sectional } \\
\text { estimates }\end{array}$ & $\begin{array}{l}\text { Sibling difference } \\
\text { estimates }\end{array}$ \\
\hline & $\begin{array}{ll}\text { MS } & \text { RS }\end{array}$ & SMS $\quad$ SRS \\
\hline
\end{tabular}

Mothers' part-time employment:

$\begin{array}{ccccc}\begin{array}{c}\text { Child aged } 0-5 \\ (+1 \text { year })\end{array} & 0.001 & -0.005 & -0.033 & -0.064 \\ & (0.097) & (0.342) & (2.128) & (1.828) \\ \begin{array}{c}\text { Child aged 6-10 } \\ \quad+1 \text { year })\end{array} & -0.004 & 0.003 & 0.020 & -0.007 \\ & (0.547) & (0.352) & (0.844) & (0.173) \\ \begin{array}{c}\text { Child aged 11-15 } \\ \quad+1 \text { year })\end{array} & 0.012 & 0.012 & -0.027 & -0.041 \\ \quad(1.865) & (1.519) & (0.708) & (0.627)\end{array}$

Mother's full-time employment:

\begin{tabular}{|c|c|c|c|c|}
\hline $\begin{array}{l}\text { Child aged } 0-5 \\
\qquad(+1 \text { year })\end{array}$ & $\begin{array}{l}-0.008 \\
(0.405)\end{array}$ & $\begin{array}{l}-0.034 \\
(1.199)\end{array}$ & $\begin{array}{l}-0.075 \\
(2.731)\end{array}$ & $\begin{array}{l}-0.105 \\
(2.404)\end{array}$ \\
\hline $\begin{array}{l}\text { Child aged } 6-10 \\
\qquad(+1 \text { year })\end{array}$ & $\begin{array}{l}-0.018 \\
(1.114)\end{array}$ & $\begin{array}{c}0.009 \\
(0.438)\end{array}$ & $\begin{array}{c}0.081 \\
(2.596)\end{array}$ & $\begin{array}{c}0.045 \\
(0.802)\end{array}$ \\
\hline $\begin{array}{c}\text { Child aged } 11-15 \\
\qquad+1 \text { year })\end{array}$ & $\begin{array}{l}0.029 \\
(2.983)\end{array}$ & $\begin{array}{c}0.024 \\
(2.013)\end{array}$ & $\begin{array}{c}0.002 \\
(0.063)\end{array}$ & $\begin{array}{l}-0.036 \\
(0.799)\end{array}$ \\
\hline $\begin{array}{l}\text { 'ather's employmen } \\
\text { Child aged } 0-5 \\
\text { (+ } 1 \text { year })\end{array}$ & $\begin{array}{c}0.029 \\
(1.905)\end{array}$ & $\begin{array}{c}0.034 \\
(2.352)\end{array}$ & $\begin{array}{l}-0.039 \\
(1.887)\end{array}$ & $\begin{array}{l}-0.031 \\
(1.188)\end{array}$ \\
\hline $\begin{array}{l}\text { Child aged 6-10 } \\
\qquad(+1 \text { year })\end{array}$ & $\begin{array}{l}0.016 \\
(1.025)\end{array}$ & $\begin{array}{l}-0.001 \\
(0.045)\end{array}$ & $\begin{array}{c}0.005 \\
(0.177)\end{array}$ & $\begin{array}{c}0.012 \\
(0.793)\end{array}$ \\
\hline $\begin{array}{l}\text { Child aged } 11-15 \\
\qquad(+1 \text { year })\end{array}$ & $\begin{array}{l}-0.009 \\
(0.542)\end{array}$ & $\begin{array}{c}0.018 \\
(0.947)\end{array}$ & $\begin{array}{l}-0.020 \\
(0.573)\end{array}$ & $\begin{array}{c}0.018 \\
(0.795)\end{array}$ \\
\hline$N$ & 1,026 & 647 & 381 & 187 \\
\hline
\end{tabular}

Note: Family structure enters by developmental stage. For all the other variables used in the estimation see note of Table 2. 
Table A1: Effects of other variables on the probability of achieving A level or more (Absolute ratios of coefficient to standard error are shown in parentheses)

\begin{tabular}{|c|c|c|c|c|}
\hline \multirow[b]{2}{*}{ Variable } & \multicolumn{2}{|c|}{$\begin{array}{l}\text { Cross-sectional } \\
\text { estimates }\end{array}$} & \multicolumn{2}{|c|}{$\begin{array}{l}\text { Sibling difference } \\
\text { estimates }\end{array}$} \\
\hline & MS & $\mathrm{RS}$ & SMS & SRS \\
\hline Female & $\begin{array}{c}0.013 \\
(0.448)\end{array}$ & $\begin{array}{c}0.020 \\
(0.553)\end{array}$ & $\begin{array}{c}0.015 \\
(0.388)\end{array}$ & $\begin{array}{c}0.021 \\
(0.750)\end{array}$ \\
\hline Year of birth - 1900 & $\begin{array}{c}0.026 \\
(2.709)\end{array}$ & $\begin{array}{c}0.038 \\
(1.559)\end{array}$ & & \\
\hline Age & & & $\begin{array}{c}0.005 \\
(0.844)\end{array}$ & $\begin{array}{r}0.009 \\
(0.681)\end{array}$ \\
\hline Age 19 & $\begin{array}{c}0.198 \\
(3.379)\end{array}$ & $\begin{array}{c}0.195 \\
(3.149)\end{array}$ & & \\
\hline Age 20 & $\begin{array}{c}0.295 \\
(4.779)\end{array}$ & $\begin{array}{c}0.288 \\
(3.890)\end{array}$ & & \\
\hline Age 21 & $\begin{array}{c}0.336 \\
(5.250)\end{array}$ & $\begin{array}{c}0.352 \\
(3.992)\end{array}$ & & \\
\hline Age 22 & $\begin{array}{c}0.376 \\
(5.269)\end{array}$ & $\begin{array}{c}0.411 \\
(3.759)\end{array}$ & & \\
\hline Age 23 or more & $\begin{array}{c}0.397 \\
(5.139)\end{array}$ & $\begin{array}{c}0.428 \\
(3.326)\end{array}$ & & \\
\hline \multicolumn{5}{|l|}{ Ever in single-parent family: } \\
\hline Child aged 0-5 & $\begin{array}{l}-0.130 \\
(2.669)\end{array}$ & $\begin{array}{l}-0.099 \\
(2.703)\end{array}$ & $\begin{array}{l}-0.154 \\
(2.203)\end{array}$ & $\begin{array}{l}-0.213 \\
(3.902)\end{array}$ \\
\hline Age of mother at birth $\leq 21$ & $\begin{array}{l}-0.078 \\
(1.533)\end{array}$ & $\begin{array}{l}-0.043 \\
(0.652)\end{array}$ & $\begin{array}{l}-0.065 \\
(0.847)\end{array}$ & $\begin{array}{l}-0.081 \\
(1.893)\end{array}$ \\
\hline Age of mother at birth $\geq 35$ & $\begin{array}{c}0.011 \\
(0.132)\end{array}$ & $\begin{array}{c}0.182 \\
(1.198)\end{array}$ & $\begin{array}{c}0.077 \\
(1.116)\end{array}$ & $\begin{array}{c}0.063 \\
(0.496)\end{array}$ \\
\hline Age of father at birth $\leq 21$ & $\begin{array}{c}0.092 \\
(1.252)\end{array}$ & $\begin{array}{c}0.186 \\
(1.951)\end{array}$ & $\begin{array}{l}-0.043 \\
(1.136)\end{array}$ & $\begin{array}{c}0.135 \\
(1.107)\end{array}$ \\
\hline Age of father at birth $\geq 37$ & $\begin{array}{c}0.130 \\
(1.822)\end{array}$ & $\begin{array}{c}0.018 \\
(0.214)\end{array}$ & $\begin{array}{c}0.022 \\
(0.190)\end{array}$ & $\begin{array}{r}0.064 \\
(0.321)\end{array}$ \\
\hline Number of brothers & $\begin{array}{l}-0.021 \\
(1.022)\end{array}$ & $\begin{array}{l}-0.021 \\
(0.828)\end{array}$ & & \\
\hline Number of sisters & $\begin{array}{l}-0.025 \\
(1.144)\end{array}$ & $\begin{array}{l}-0.035 \\
(1.264)\end{array}$ & & \\
\hline Firstborn & $\begin{array}{l}-0.005 \\
(0.026)\end{array}$ & $\begin{array}{c}0.001 \\
(0.011)\end{array}$ & $\begin{array}{c}0.036 \\
(0.769)\end{array}$ & $\begin{array}{c}0.052 \\
(1.328)\end{array}$ \\
\hline Only child & $\begin{array}{c}0.040 \\
(0.586)\end{array}$ & $\begin{array}{c}0.009 \\
(0.101)\end{array}$ & & \\
\hline Mother's education: & & & & \\
\hline Less than $\mathrm{O}$ level & $\begin{array}{c}0.050 \\
(1.072)\end{array}$ & $\begin{array}{c}0.065 \\
(1.117)\end{array}$ & & \\
\hline O level & $\begin{array}{c}0.078 \\
(1.976)\end{array}$ & $\begin{array}{c}0.107 \\
(2.193)\end{array}$ & & \\
\hline A level & $\begin{array}{c}0.137 \\
(2.215)\end{array}$ & $\begin{array}{c}0.144 \\
(1.936)\end{array}$ & & \\
\hline
\end{tabular}




\begin{tabular}{|c|c|c|c|c|}
\hline Higher vocational quals. & $\begin{array}{c}0.183 \\
(4.269)\end{array}$ & $\begin{array}{l}0.238 \\
(4.430)\end{array}$ & & \\
\hline Higher qualification & $\begin{array}{l}0.208 \\
(2.863)\end{array}$ & $\begin{array}{l}0.256 \\
(2.952)\end{array}$ & & \\
\hline \multicolumn{5}{|l|}{ Father's education: } \\
\hline Less than $\mathrm{O}$ level & $\begin{array}{c}0.055 \\
(0.910)\end{array}$ & $\begin{array}{c}0.049 \\
(0.604)\end{array}$ & & \\
\hline O level & $\begin{array}{c}0.041 \\
(0.891)\end{array}$ & $\begin{array}{c}0.051 \\
(0.892)\end{array}$ & & \\
\hline A level & $\begin{array}{c}0.097 \\
(1.694)\end{array}$ & $\begin{array}{l}0.126 \\
(1.839)\end{array}$ & & \\
\hline Higher vocational quals. & $\begin{array}{c}0.147 \\
(3.284)\end{array}$ & $\begin{array}{l}0.132 \\
(2.400)\end{array}$ & & \\
\hline Higher qualification & $\begin{array}{c}0.251 \\
(3.245)\end{array}$ & $\begin{array}{c}0.233 \\
(2.552)\end{array}$ & & \\
\hline Father is missing ( $1=$ yes $)$ & $\begin{array}{c}0.056 \\
(0.940)\end{array}$ & $\begin{array}{c}0.081 \\
(1.105)\end{array}$ & $\begin{array}{l}-0.040 \\
(1.272)\end{array}$ & $\begin{array}{l}-0.062 \\
(0.752)\end{array}$ \\
\hline $\begin{array}{l}\text { Information on father's work } \\
\text { is missing ( } 1=y e s)\end{array}$ & $\begin{array}{c}0.427 \\
(1.862)\end{array}$ & $\begin{array}{l}0.496 \\
(2.208)\end{array}$ & $\begin{array}{l}-0.401 \\
(0.445)\end{array}$ & $\begin{array}{l}-0.348 \\
(0.840)\end{array}$ \\
\hline Log likelihood & -608 & -365 & -235 & -109 \\
\hline$N$ & 1,026 & 647 & 381 & 187 \\
\hline
\end{tabular}

Note: See Table 2 for other estimates. 


\section{IZA Discussion Papers}

No Author(s)

121 J. C. van Ours

122 D. Munich

J. Svejnar

K. Terrell

123 J. Hunt

124 R. T. Riphahn

125 F. Büchel

J. R. Frick

126 J. Fersterer

R. Winter-Ebmer

127 M. Karanassou

D. J. Snower

128 O. Ashenfelter

D. Ashmore

O. Deschênes

129 B. R. Chiswick

M. E. Hurst

130

G. Brunello

S. Comi

C. Lucifora

131

132

133

D. N. F. Bell

R. A. Hart

O. Hübler

W. Schwerdt

134 A. D. Kugler

G. Saint-Paul

135 A. Barrett

P. J. O'Connell

136 M. Bräuninger

M. Pannenberg
Titel

Area

Date

Do Active Labor Market Policies Help Unemployed $\quad 4 / 6$

Workers to Find and Keep Regular Jobs?

$3 / 00$

Returns to Human Capital under the Communist

4

$3 / 00$

Wage Grid and During the Transition to a Market

Economy

Why Do People Still Live in East Germany?

$3 / 00$

Rational Poverty or Poor Rationality? The Take-up 3

of Social Assistance Benefits

The Income Portfolio of Immigrants in Germany -

Effects of Ethnic Origin and Assimilation. Or:

Who Gains from Income Re-Distribution?

Smoking, Discount Rates, and Returns to

Education

Characteristics of Unemployment Dynamics: The

Chain Reaction Approach

Do Unemployment Insurance Recipients Actively

Seek Work? Evidence From Randomized Trials in

Four U.S. States

The Employment, Unemployment and

Unemployment Compensation Benefits of Immigrants

The Returns to Education in Italy: A New Look at 5 the Evidence

5

$3 / 00$

$3 / 00$

$3 / 00$

$3 / 00$

$3 / 00$

Are Immigrants Favorably Self-Selected? An 1

Economic Analysis

Hours and Wages in the Depression: British 7 Engineering, 1926-1938

Paid and Unpaid Overtime Working in Germany and 1 the UK

$3 / 00$

Hiring and Firing Costs, Adverse Selection and

3

$3 / 00$

Long-term Unemployment

Is There a Wage Premium for Returning Irish

1

$3 / 00$

Migrants?

Unemployment and Productivity Growth: An

3

$3 / 00$

Empirical Analysis within the Augmented Solow Model 
139 R. A. Hart

Y. Ma

140 G. Brunello

S. Comi

141 R. Hujer

M. Wellner

142 J. J. Dolado

F. Felgueroso

J. F. Jimeno

143 P. J. Luke

M. E. Schaffer

144 G. Saint-Paul

145 M.-S. Yun

146 T. K. Bauer

J. P. Haisken-DeNew

147 M. Belot

J. C. van Ours

148 L. Goerke

149 R. Lalive

J. C. van Ours

J. Zweimüller

150 J. DiNardo

K. F. Hallock

J.-St. Pischke

151 M. Ward

152 J. J. Dolado

F. Felgueroso

J. F. Jimeno

153 A. S. Kalwij

M. Gregory

154 M. Gerfin

M. Lechner
Wages, Hours and Human Capital over the

Life Cycle

Education and Earnings Growth: Evidence from 11

European Countries

The Effects of Public Sector Sponsored Training on Individual Employment Performance in East Germany

Explaining Youth Labor Market Problems in Spain: 3

Crowding-Out, Institutions, or Technology Shifts?

Wage Determination in Russia: An Econometric 4

Investigation

Flexibility vs. Rigidity: Does Spain have the worst of 1 both Worlds?

Decomposition Analysis for a Binary Choice Model 7

Employer Learning and the Returns to Schooling 5

Does the Recent Success of Some OECD

Countries in Lowering their Unemployment Rates

Lie in the Clever Design of their Labour Market

Reforms?

Employment Effects of Labour Taxation in an Efficiency Wage Model with Alternative Budget Constraints and Time Horizons

The Impact of Active Labor Market Programs and Benefit Entitlement Rules on the Duration of Unemployment

Unions and the Labor Market for Managers

Gender, Salary and Promotion in the Academic 5 Profession

The Role of the Minimum Wage in the Welfare 3 State: An Appraisal

Overtime Hours in Great Britain over the Period 3 1975-1999: A Panel Data Analysis

Microeconometric Evaluation of the Active Labour 6 Market Policy in Switzerland 
R. Rees

Household Production, Full Consumption and $\quad 7$

A Comparison of the Human Capital and Signaling Models: The Case of the Self-Employed and the Increase in the Schooling Premium in the 1980's 
174 E. Fehr J.-R. Tyran

175 M. Lofstrom

176

O. Hübler

W. Meyer

177 B. R. Chiswick

G. Repetto

178 R. Euwals

M. Ward

179 E. Wasmer

P. Weil

180 T. K. Bauer

I. N. Gang

181

E. Wasmer

Y. Zenou

182 M. Fertig

C. M. Schmidt

183 M. Fertig

184 M. Corak

B. Gustafsson

T. Österberg

185 H. Bonin

K. F. Zimmermann

186

C. Dustmann

187

T. K. Bauer

M. Lofstrom

K. F. Zimmermann
C. M. Schmidt

Does Money Illusion Matter? An Experimental

Approach

Self-Employment and Earnings among High-

Skilled Immigrants in the United States

Industrial Relations and the Wage Differentials

between Skilled and Unskilled Blue-Collar

Workers within Establishments: An Empirical

Analysis with Data of Manufacturing Firms

Immigrant Adjustment in Israel: Literacy and

Fluency in Hebrew and Earnings

The Renumeration of British Academics

5

The Macroeconomics of Labor and Credit Market Imperfections

Sibling Rivalry in Educational Attainment:

The German Case

Space, Search and Efficiency

2

$8 / 00$

Discretionary Measures of Active Labor Market Policy: The German Employment Promotion Reform in Perspective

Aggregate-Level Migration Studies as a Tool for 1 Forecasting Future Migration Streams

Intergenerational Influences on the Receipt of 3 Unemployment Insurance in Canada and Sweden

The Post-Unification German Labor Market

4

$8 / 00$

Temporary Migration and Economic Assimilation

$8 / 00$

Immigration Policy, Assimilation of Immigrants and 1

$8 / 00$

Natives' Sentiments towards Immigrants: Evidence from 12 OECD-Countries

The Myth of Worksharing

5

$8 / 00$

A. S. Kalwij

A. Zaidi 

190
C. Dustmann
I. Preston
191
G. C. Giannelli
C. Monfardini

192

G. Brunello

193

A. Kunze

194

A. Newell

F. Pastore

195 F. Büchel

A. Mertens

196 J. S. Earle

K. Z. Sabirianova

197
G. A. Pfann

M. Kreyenfeld

C. K. Spiess

G. G. Wagner

199 H. Entorf

200

T. Bauer

G. S. Epstein

I. N. Gang

201

T. J. Dohmen

G. A. Pfann

202

P. Francois

J. C. van Ours

203
J. M. Abowd
F. Kramarz
D. N. Margolis
T. Philippon

204

G. S. Epstein
A. L. Booth
M. Francesconi

J. Frank

206 C. M. Schmidt

R. Baltussen

R. Sauerborn
Racial and Economic Factors in Attitudes to

1

$8 / 00$

Immigration

Joint Decisions on Household Membership and

Human Capital Accumulation of Youths: The role of

expected earnings and local markets

Absolute Risk Aversion and the Returns to

5

$8 / 00$

Education

The Determination of Wages and the Gender

Wage Gap: A Survey

5

$8 / 00$

Regional Unemployment and Industrial

4

$8 / 00$

Restructuring in Poland

Overeducation, Undereducation, and the Theory

5

of Career Mobility

$9 / 00$

Equilibrium Wage Arrears: A Theoretical and 4 Empirical Analysis of Institutional Lock-In

$9 / 00$

Options to Quit

$9 / 00$

A Forgotten Issue: Distributional Effects of Day

3

Care Subsidies in Germany

$9 / 00$

Rational Migration Policy Should Tolerate Non-

$9 / 00$

Zero Illegal Migration Flows: Lessons from

Modelling the Market for Illegal Migration

What are Migration Networks?

$9 / 00$

Worker Separations in a Nonstationary Corporate 1 Environment

$9 / 00$

Gender Wage Differentials in a Competitive Labor 5 Market: The Household Interaction Effect

The Tail of Two Countries: Minimum Wages and 5 Employment in France and the United States

$9 / 00$

Labor Market Interactions Between Legal and

$10 / 00$ Illegal Immigrants

Temporary Jobs: Stepping Stones or Dead Ends? 1

$10 / 00$

The Evaluation of Community-Based Interventions: Group-Randomization, Limits and Alternatives 
